\title{
Factors Relating to the Utilization of Health Services at the Naioni Community Health Center (Puskesmas) in Alak Subdistrict, Kupang City in 2021
}

\author{
Widya Y. Nurdin ${ }^{1 *}$, Tadeus A. L. Regaletha ${ }^{1}$, Dominirsep O. Dodo ${ }^{1}$
}

${ }^{1}$ Public Health Faculty, University of Nusa Cendana

Article History
Received: 14.11 .2021
Accepted: 19.12 .2021
Published: 21.01 .2022
Journal homepage:
https://www.easpublisher.com
Quick Response Code

\begin{abstract}
Every health service must have a goal so that the highest level of health can be achieved. One of the health service facilities that have a goal is the puskesmas. Puskesmas is a health service facility that organizes primary health efforts, namely health efforts that become the community's first contact with health services. This study was conducted to determine the relationship between education level, occupation, accessibility, facilities and facilities, staff attitudes, and family support with the utilization of health services at the Naioni Community Health Center, Alak District. The type of research used is descriptive research with a quantitative approach. The method used is a cross sectional study. To obtain data in the field is done by interviewing using a questionnaire to 99 respondents and taken by cluster sampling. Respondents in this study were residents who were in the working area of the Naioni Community Health Center which consisted of 3 villages, namely Naioni Village (18 respondents), Manulai II Village (46 respondents), and Batuplat Village (35 respondents). The results of the study were analyzed using thetest chi-square showing that there is a relationship between accessibility ( $\mathrm{p}=$ $0.000)$, facilities and facilities $(p=0.007)$, attitude of officers $(p=0.000)$, and family support $(\mathrm{p}=0.000)$ with the utilization of health services in Naioni Community Health Center. While the variables of occupation $(p=0.325)$ and education $(\mathrm{p}=0.258)$ did not have a relationship with the utilization of health services at the Naioni Health Center, Alak District, Kupang City.

Keywords: Health Services, Occupations, Health Facilities, Attitude of Health Personnel, Health Status.
\end{abstract}

Copyright (C) 2022 The Author(s): This is an open-access article distributed under the terms of the Creative Commons Attribution 4.0 International License (CC BY-NC 4.0) which permits unrestricted use, distribution, and reproduction in any medium for non-commercial use provided the original author and source are credited.

\section{INTRODUCTION}

Health development is an effort made by all Indonesian people which aims to increase awareness, willingness, and ability to live a healthy life so as to create the highest degree of health. The efforts that can be made are living and behaving in a healthy environment, and having access to health services [1].

Health service facility is a tool or place used to organize health service efforts, whether promotive, preventive, or rehabilitative carried out by the government, regional government, and/or the community [2].

One of the health service facilities is the Puskesmas. Community Health Center or Puskesmas is a health service facility that organizes public health efforts and first-level individual health efforts, by prioritizing promotive and preventive efforts in their working areas [3].
The Naioni Health Center is a non-hospitalized health center located in Naioni Village, Alak District. From Kupang City Health Profile data, the number of outpatient visits to the Naioni Health Center from 20152017 increased to 13,635 patients [4]. However, from 2018 to 2020 , it decreased to 10,592 patients. The declining number of visits at the puskesmas in 2020 shows that the health services at the puskesmas have not been fully utilized by the community. Apart from that, the distance to the puskesmas is from Batuplat subdistrict it reaches $9.0 \mathrm{~km}$ with a travel time of 18 minutes and from Manulai II village it reaches $8.2 \mathrm{~km}$ with a travel time of 17 minutes if using a private vehicle. Meanwhile, there is no public transportation to get to the Naioni Health Center. Another factor is the lack of complete facilities and health workers at Pustu Naioni.

In making health services effective for the community, a health service must be available and sustainable, acceptable and reasonable, easily accessible and easily accessible and of good quality [5]. 
Lawrence Green analyzes human attitudes from the level of health. The health of a person or society is determined by two factors, namely the attitude factor and the non-attitude factor. Attitude factors come from three factors, namely predisposing factors, supporting factors, and driving factors [6].

Predisposing factors include beliefs, beliefs, occupations, attitudes, education, and knowledge. The results of related studies show that there is a significant relationship between education and employment variables on decision making in utilizing health services at the puskesmas [7].

Supporting factors include the presence or absence of health facilities and facilities as well as the physical environment. The driving factors include the behavior and attitudes of health workers and families. The results of related studies indicate that there is a significant relationship between the variables of facilities and infrastructure, accessibility, attitudes of health workers, and family support on decision making in utilizing health services at the puskesmas [8].

There are factors at the Naioni Health Center, so that people sometimes prefer to have health care facilities that are more complete and closer to their homes. In addition, so far there has been no research regarding the factors related to the utilization of health services at the Naioni Health Center to determine the effectiveness of the Puskesmas in the area so that researchers are encouraged to conduct research at the Naioni Health Center.

\section{MeTHODS}

The type of research used is analytic survey research using a quantitative approach and using a cross sectional study design to determine the relationship between education, employment, accessibility, facilities and facilities, staff attitudes, and family support with the use of health services in the working area of the Naioni Health Center. Cross sectional study is an observation of the dependent variable and the independent variable carried out at the same time so that illustrations and correlations can be obtained between risk factors and influencing factors in the target population [9].

Sampling in this study used the Slovin formula so that a large sample of 99 people was obtained. Details of the sample size of each kelurahan that must be taken using the cluster sampling technique. So that the sample size for each village in the working area of the Naioni Health Center is 18 people in Naioni Village, 46 people in Manulai II Village, and 35 people in Batuplat Village. Presentation of data in this study in the form of tables and narratives.

\section{RESULTS}

Variable data in the working area of the Naioni Health Center can be seen in table 1 which shows that most respondents do not use the Puskesmas (54\%), moderate education level (39\%), do not work (57\%), easy access to puskesmas (76\%), complete facilities and facilities at the puskesmas $(57 \%)$, good attitude of officers $(51 \%)$, and poor family support $(59 \%)$. While table 2 shows the results of bivariate analysis using the chi-square test.

Table-1: Frequency Distribution of Factors Affecting the Utilization of Health Services at the Naioni Health Center in 2021

\begin{tabular}{|c|c|c|}
\hline \multirow[t]{2}{*}{ Variable } & \multicolumn{2}{|c|}{ Total Respondents } \\
\hline & $\mathbf{n}$ & $\%$ \\
\hline \multicolumn{3}{|c|}{ Variable Dependent } \\
\hline \multicolumn{3}{|c|}{ Health Center Utilization } \\
\hline Not Utilizing & 54 & 54,5 \\
\hline Utilizing & 45 & 45,5 \\
\hline Total & 99 & 100 \\
\hline \multicolumn{3}{|c|}{ Variable Independent } \\
\hline \multicolumn{3}{|l|}{ Education } \\
\hline Low & 33 & 33,3 \\
\hline Currently & 39 & 39,4 \\
\hline Tall & 27 & 27,3 \\
\hline Total & 99 & 100 \\
\hline \multicolumn{3}{|l|}{ Work } \\
\hline Not work & 57 & 57,6 \\
\hline Work & 42 & 42,4 \\
\hline Total & 99 & 100 \\
\hline \multicolumn{3}{|l|}{ Accessibility } \\
\hline Difficult Access & 23 & 23,2 \\
\hline Easy Access & 76 & 76,8 \\
\hline Total & 99 & 100 \\
\hline \multicolumn{3}{|c|}{ Facilities and Facilities } \\
\hline Incomplete & 42 & 42,4 \\
\hline Complete & 57 & 57,6 \\
\hline Total & 99 & 100 \\
\hline \multicolumn{3}{|c|}{ Officer's Attitude } \\
\hline Not Good & 48 & 48,5 \\
\hline Good & 51 & 51,5 \\
\hline Total & 99 & 100 \\
\hline \multicolumn{3}{|l|}{ Family support } \\
\hline Not Good & 59 & 59,6 \\
\hline Good & 40 & 40,4 \\
\hline Total & 99 & 100 \\
\hline
\end{tabular}

The results showed that in the group of respondents with a low level of education, most of the respondents $(54.5 \%)$ used health services at the Naioni Health Center. As for the group of respondents with moderate education level, most of the respondents $(53.8 \%)$ did not use health services at the Naioni Health Center. While the group of respondents with a higher education level, most of the respondents $(66.7 \%) \mathrm{did}$ not use health services at the Naioni Health Center. The results of the bivariate test showed that statistically, a p- 
value of $0.258>0.05$ was obtained, which means that there is no relationship between education and the utilization of the Puskesmas.

In the group of respondents who do not work, most of the respondents $(59.6 \%)$ do not use health services at the Naioni Health Center. While the group of respondents who worked, most of the respondents $(52.4 \%)$ used health services at the Naioni Health Center. The results of the bivariate test showed that statistically, a p-value of $0.325>0.05$ was obtained, which means that there is no relationship between work and the utilization of the Puskesmas.

Table-2: The Relationship between Independent Variables and Utilization of Health Services at the Naioni Health Center in 2021

\begin{tabular}{|c|c|c|c|c|}
\hline \multirow[t]{3}{*}{ Variable } & \multicolumn{3}{|c|}{ Utilization of Health Services at the Puskesmas } & \multirow[t]{3}{*}{$p$-value } \\
\hline & Not Utilizing & Utilizing & Total & \\
\hline & n $(\%)$ & n $(\%)$ & n $(\%)$ & \\
\hline \multicolumn{4}{|l|}{ Education } & \multirow[t]{5}{*}{0,258} \\
\hline Low & $15(45,5)$ & $18(54,5)$ & $33(100)$ & \\
\hline Currently & $21(53,8)$ & $18(46,2)$ & $39(100)$ & \\
\hline Tall & $18(66,7)$ & $9(33,3)$ & $27(100)$ & \\
\hline Total & $54(54,5)$ & $45(45,5)$ & $99(100)$ & \\
\hline \multicolumn{4}{|l|}{ Work } & \multirow[t]{4}{*}{0,325} \\
\hline Not work & $34(59,6)$ & $23(40,4)$ & $57(100)$ & \\
\hline Work & $20(47,6)$ & $22(52,4)$ & $42(100)$ & \\
\hline Total & $54(54,4)$ & $45(45,5)$ & $99(100)$ & \\
\hline \multicolumn{4}{|l|}{ Accessibility } & \multirow[t]{4}{*}{0,000} \\
\hline Difficult Access & $22(95,7)$ & $1(4,3)$ & $23(100)$ & \\
\hline Easy Access & $32(42,1)$ & $44(57,9)$ & $76(100)$ & \\
\hline Total & $54(54,5)$ & $45(45,5)$ & $99(100)$ & \\
\hline \multicolumn{4}{|c|}{ Facilities and Facilities } & \multirow[t]{4}{*}{0,007} \\
\hline Incomplete & $30(71,4)$ & $12(28,6)$ & $42(100)$ & \\
\hline Complete & $24(42,1)$ & $33(57,9)$ & $57(100)$ & \\
\hline Total & $54(54,5)$ & $45(45,5)$ & $99(100)$ & \\
\hline \multicolumn{4}{|c|}{ Officer's Attitude } & \multirow[t]{4}{*}{0,000} \\
\hline Not Good & $47(97,9)$ & $1(2,1)$ & $48(100)$ & \\
\hline Good & $7(13,7)$ & $44(86,3)$ & $51(100)$ & \\
\hline Total & $54(54,5)$ & $45(45,5)$ & $99(100)$ & \\
\hline \multicolumn{4}{|l|}{ Family support } & \multirow[t]{4}{*}{0,000} \\
\hline Not Good & $52(88,1)$ & $7(11,9)$ & $59(100)$ & \\
\hline Good & $2(5,0)$ & $38(95,0)$ & $40(100)$ & \\
\hline Total & $54(54,5)$ & $45(45,5)$ & $99(100)$ & \\
\hline
\end{tabular}

In the group of respondents who assessed that access to puskesmas was difficult, most of the respondents $(95.7 \%)$ did not take advantage of health services at the Naioni Health Center. While the group of respondents who assessed that access to the puskesmas was easy, most of the respondents $(57.9 \%)$ used health services at the Naioni Health Center. The results of the bivariate test showed that statistically, a p-value of $0.000<0.05$ was obtained, which means that there is a relationship between accessibility and utilization of the Puskesmas.

In the group of respondents who assessed that the facilities and facilities at the Puskesmas were incomplete, most of the respondents $(71.4 \%)$ did not utilize the health services at the Naioni Health Center. While the group of respondents who assessed that the facilities and facilities at the Puskesmas were complete, most of the respondents $(57.9 \%)$ used health services at the Naioni Health Center. The results of the bivariate test showed that statistically, a p-value of $0.007<0.05$ was obtained, which means that there is a relationship between facilities and facilities and the utilization of the Puskesmas.

In the group of respondents who assessed that the attitude of the officers at the puskesmas was not good, most of the respondents $(97.9 \%)$ did not take advantage of the health services at the Naioni Health Center. While the group of respondents who assessed that the attitude of the officers at the Puskesmas was good, most of the respondents $(86.3 \%)$ used health services at the Naioni Health Center. The results of the bivariate test showed that statistically, a p-value of $0.000<0.05$ was obtained, which means that there was a relationship between the attitude of the officers and the utilization of the Puskesmas.

In the group of respondents who considered that their family support was not good enough, most of 
the respondents $(88.1 \%)$ did not take advantage of the health services at the Naioni Health Center. While the group of respondents who considered that there was good family support, most of the respondents $(95.0 \%)$ used health services at the Naioni Health Center. The results of the bivariate test showed that statistically, a pvalue of $0.000<0.05$ was obtained, which means that there was a relationship between family support and the utilization of the Puskesmas.

\section{DISCUSSION}

\section{Relationship of Educational Factors with Utilization of Puskesmas}

Educational status is closely related to a person's awareness and knowledge, as a result, educational status has a very large impact on the use of health services because in general people who have low levels of education lack awareness and good knowledge about the use of health services [10].

Theoretically, if someone has a high formal education will have higher knowledge than someone who has a low education, so that formal education will affect a person's knowledge [11].

The results of this study indicate that based on the level of education, it can be seen that respondents with moderate and high education, the majority of respondents do not use health services at the Puskesmas. As for the low level of education, the majority of respondents chose to use health services at the Puskesmas. Based on the results of the bivariate analysis of the chi-square test, it was found that Ho in this study was accepted, meaning that there was no relationship between a level of education and the utilization of health services at the Naioni Health Center. Respondents who do not use health services at the Puskesmas prefer to self-medicate by buying drugs in stores or pharmacies based on their experience and the majority of respondents only suffer from mild illnesses such as coughs and colds which do not interfere with the respondent's activities, so they do not force them to take advantage of health services.

The results of this study are in line with research by Fatimah that there is no significant relationship between education and utilization of health services $(p$-value $=1,000)$. This is because there is no difference between education levels so that both people with high and low education continue to use health services at the Puskesmas. The high and low level of education does not necessarily guarantee to take advantage of a health service, but knowledge and information that influence a person in making decisions to utilize health services [12].

\section{Relationship between Occupational Factors and Utilization of Puskesmas}

Work is not a source of pleasure, but a way of earning a living, repetitive and challenging. Work is a necessity that must be done especially to support life and family life [13].

The results of this study indicate that more respondents who are in the working area of the Naioni Health Center do not work or as housewives who work at home. Based on the results of the bivariate analysis of the chi-square test, it was found that Ho in this study was accepted, meaning that there was no relationship between employment and the utilization of health services at the Naioni Health Center. Respondents who have jobs and those who do not have jobs can take advantage of health services at the Puskesmas because the distance from the respondents' homes is relatively close to the Puskesmas. In addition, respondents who work more often use the Puskesmas on Saturdays or on holidays.

The results of this study are in line with research by Hidana that there is no significant relationship between work and utilization of health services ( $\mathrm{p}$-value $=0.883$ ). This is because there is no or there is a job, is not a consideration in utilizing a health service facility. A person who works tends to have limited time in utilizing health services at the Puskesmas in the morning; as a result most of them prefer other health service facilities that are open in the afternoon or outside their working hours. As a result, work is not a benchmark in utilizing health services [14].

\section{Relationship between Accessibility Factors and Utilization of Puskesmas}

Accessibility to a health service must be achievable and not hindered by geographical, economic, organizational, linguistic and social conditions. Geographical conditions must be measured by distance, travel time, means of transportation and other physical obstacles that can hinder the use of a health service [11].

The results of this study indicate that there are more respondents who say access to Puskesmas is easy than respondents who say access to Puskesmas is difficult. Respondents who said that access to the Puskesmas was difficult, most of them did not use the Puskesmas because transportation was difficult to reach the Puskesmas, and there were other health service facilities that were closer to the respondent's residence.

The respondents who said that access to the puskesmas was easy, most of them used the puskesmas because the respondents lived near the puskesmas. So that the distance traveled is not far, the transportation costs incurred are not much, and the travel time to health service facilities is relatively fast.

Based on the results of the bivariate analysis of the chi-square test, it was found that Ho in this study was rejected, meaning that there was a relationship 
between accessibility to the utilization of health services at the Naioni Health Center. The results of this study are in line with research by Masita that there is a significant relationship between accessibility to the use of health services ( $p$-value $=0.009$ ). This is because the easier the accessibility to health services, the higher the level of utilization of health services. One of the factors that enable the utility of health services is accessibility. A health service that is located far from the place of residence is certainly difficult to reach, so it requires transportation that supports it to reach health care facilities, if this situation really occurs, it will certainly make the patient feel dissatisfied [15].

\section{The Relationship of Facilities and Facilities Factors with the Utilization of the Health Center}

The completeness of examination equipment, various drugs, cleanliness and comfort provided are very important factors to attract patients who can be a guarantee for the development of treatment at the Puskesmas, so there is a need for supporting facilities and facilities in health services. Facilities are all things that can be used as a tool in order to achieve a goal and things that can support the implementation of a process of receiving or receiving health services. The facility is another part which is said to affect the utilization of a health service because it can affect the length of waiting time in getting a dream health service. With the facilities, waiting time feels more fun [16].

The results of this study prove that the respondents who considered that the facilities and facilities were complete were more than the respondents who considered that the facilities and facilities were incomplete at the Naioni Health Center. Respondents who assessed that the facilities were incomplete, most of them did not use the Puskesmas because respondents preferred to other health service facilities which according to respondents had more complete facilities such as hospitals or other health centers.

As for the respondents who assessed that the facilities were complete, most of them used the Puskesmas because the respondents considered that the facilities at the puskesmas were adequate and could meet the needs of the respondents.

Based on the results of the bivariate analysis of the chi-square test, it was found that Ho in this study was rejected, meaning that there was a relationship between facilities and facilities and the utilization of health services at the Naioni Health Center. The results of this study are in line with research by Rusdin that there is a significant relationship between facilities and facilities and the utilization of health services ( $p$-value $=$ 0.0044). This is because the availability of facilities and facilities can encourage or motivate the community in utilizing health services at the Puskesmas. Even though the community has the intention and desire to take advantage of the services at the Puskesmas, if the facilities and facilities are inadequate, the community will choose to treat their illness themselves or go to another health service facility [17].

\section{Relationship Factors Attitude of Officers with Utilization of Puskesmas}

The attitude of health workers is interpreted as a response or reaction of health workers in carrying out a health service along with carrying out an action against the object (patient) so that it is appropriate to the patient's needs [16].

The results of this study indicate that there are more respondents who rate the attitude of the officers as good compared to respondents who think that the attitude of the officers is not good at health services at the Naioni Health Center. Respondents who assessed that the attitude of the officers was not good, most of them did not use the Puskesmas because health workers at the Pustu, such as doctors, were sometimes not in place or only on certain days. So that respondents prefer to go to other health care facilities.

As for the respondents who considered the attitude of the officers to be good, most of them used the puskesmas due to the attitude or actions of the officers in serving respondents when visiting the Puskesmas, which were considered to be respectful and friendly to the respondents.

Based on the results of the bivariate analysis of the chi-square test, it was found that Ho in this study was rejected, meaning that there was a relationship between the attitudes of the officers towards the utilization of health services at the Naioni Health Center. The results of this study are not in line with the results of research by Irawan that there is no significant relationship between the attitudes of officers towards the use of health services $(p$-value $=0.275)$. The attitude of the officers does not affect the utilization of health services because the people who choose to take advantage have no other alternative in choosing other health facilities because these people have been registered as JKN members whose medical costs are borne by the government or free of charge [18].

However, the results of this study are in line with Law Number 36 of 2014 concerning Health Workers which states that health workers have an important role to improve the quality of maximum health services to the community so that people are able to increase awareness, willingness, and ability to live healthy so that the degree of health will be realized, Highest health [19].

\section{Relationship between Family Support Factors and Utilization of Puskesmas}

The ability of families to carry out health care can be reviewed in the family health tasks carried out. Health protection provided by the family can affect the 
health status of the family, because the family plays a role in protecting health in order to prevent health problems and provide care for sick family members [20].

The results of this study indicate that respondents who assess poor family support are more than respondents who assess good family support in utilizing health services at the Naioni Health Center. Respondents who assessed that family support was not good, most of them did not use the puskesmas because families preferred to check their health with family doctors, hospitals, clinics, or other health centers whose facilities and health workers according to their families were more complete.

As for the respondents who assessed that family support was good, most of them used the puskesmas because families prefer to have their health checked at the Naioni Health Center. In addition to the close distance, there is a friendly attitude of the officers, so there is no need to go to other health facilities.

Based on the results of the bivariate analysis of the chi-square test, it was found that Ho in this study was rejected, meaning that there was a relationship between family support and the utilization of health services at the Naioni Health Center. The results of this study are in line with research by Darmawan that there is a significant relationship between family support and utilization of health services ( $\mathrm{p}$-value $=0.012$ ). The support provided by the family is support consisting of verbal or non-verbal advice or information, real help or action caused by the willingness of people who support and can affect the recipient's emotional or attitude, and then the recipient will feel cared for, loved and appreciated. The support provided by the family can increase the effectiveness of other family members in the use of health services [21].

\section{CONCLUSION}

Based on the results and discussion above, it can be concluded that there is a significant relationship between accessibility, facilities and facilities, staff attitudes, and family support on the utilization of health services at the Naioni Health Center. In addition, there is no significant relationship between education and work with the utilization of health services in the working area of the Naioni Health Center.

The puskesmas must further improve facilities, medicines, and types of services. Health workers should always be in place according to the applicable schedule and operating hours. The Puskesmas should also continue to innovate in promoting the programs or types of services available at the Puskesmas so that the community makes more use of the Puskesmas.

\section{REFERENCE}

1. Fadhilah, H. (2016). Determinan Pemanfaatan
Puskesmas Oleh Masyarakat Di Wilayah Kerja Puskesmas Sulit Air Kabupaten Solok Tahun 2016. Universitas Sumatera Utara; 2016.

2. Republik Indonesia. (2009). Undang-Undang RI No. 36 Tahun 2009 Tentang Kesehatan. 5063 Indonesia, 2, 3.

3. Kementerian, Kesehatan, R.I. (2019). Peraturan Menteri Kesehatan RI No. 43 Tahun 2019 Tentang Pusat Kesehatan Masyarakat. Indonesia, 3, 7, 11, 43.

4. Dinas, K., Kota, K. (2017). Profil Kesehatan Kota Kupang Tahun 2017. Kota Kupang; 2017.

5. Azwar, A. (2010). Pengantar Administrasi Kesehatan. Ketiga. Tangerang: Bina Rupa Aksara, 35, 36, 38, 39, 41, 120 p.

6. Notoatmodjo, S. (2010). Metodologi Penelitian Kesehatan. Jakarta: PT Rineka Cipta.

7. Kurniawan, D. (2018). Faktor Faktor Yang Mempengaruhi Masyarakat Dalam Pemanfaatan Jaminan Kesehatan Nasional Di Wilayah Kerja Puskesmas Tamalanrea Jaya Kota Makassar. Universitas Hasanuddin.

8. Harahap, S.K. (2018). Faktor-Faktor Yang Berhubungan Dalam Pemanfaatan UPTD Puskesmas Rawat Inap Gunung Tua Di Gunung Tua Kabupaten Padang Lawas Utara Tahun 2018. Universitas Sumatera Utara; 2018.

9. Wahyuni, N.S. (2015). Faktor - Faktor Yang Berhubungan Dengan Pemanfaatan Pelayanan Kesehatan Di Puskesmas Sumber Rejo Kota Balikpapan Provinsi Kalimantan Timur Tahun 2012. Universitas Indonesia.

10. Rumengan, D.S.S., Umboh, J.M.L., Kandou, G.D. (2015). Faktor-Faktor yang Berhubungan dengan Pemanfaatan Pelayanan Kesehatan Pada Peserta BPJS Kesehatan di Puskesmas Paniki Bawah Kecamatan Mapanget Kota Manado. Jikmu Suplemen [Internet], 88-100. Available from: https://ejournal.unsrat.ac.id/index.php/jikmu/articl e/view/7180

11. Notoatmodjo, S. (2003). Pendidikan dan Perilaku Kesehatan. Jakarta: PT Rineka Cipta; 2003.

12. Fatimah, S., Indrawati, F. (2019). Faktor Pemanfaatan Pelayanan Kesehatan di Puskesmas. HIGEIA [Internet], 3(1). Available from: https://journal.unnes.ac.id/sju/index.php/higeia/arti cle/view/24747/12716

13. Nursalam. (2003). Konsep dan Penerapan Metodologi Penelitian Ilmu Keperawatan Pedoman Skripsi, Tesis dan Instrumen Penelitian Keperawatan. Jakarta: Salemba Medika.

14. Hidana, R., Shaputra, R., Maryati, H. (2018). Faktor-Faktor Yang Mempengaruhi Terhadap Pemanfaatan Pelayanan Kesehatan Oleh Pasien Luar Wilayah di Puskesmas Tanah Sareal Kota Bogor Tahun 2018. Promot J Kesehat Masy, 1(2); $1-11$.

15. Masita, A., Yuniar, N., Lisnawaty. (2015). FaktorFaktor Yang Berhubungan Dengan Pemanfaatan Pelayanan Kesehatan Pasa Masyarakat Desa 
Tanailandu Di Wilayah Kerja Puskesmas KanapaNapa Kecamatan Mawasangka Kabupaten Buton Tengah Tahun 2015. Jimkesmas [Internet]. 2015; Available from: https://media.neliti.com/media/publications/18386 9-ID-faktor-faktor-yang-berhubungan-denganpe.pdf

16. Wulandari, C., Ahmad, L., Saptaputra, S. (2016). Faktor Yang Berhubungan Dengan Pemanfaatan Pelayanan Kesehatan Di Uptd Puskesmas Langara Kecamatan Wawonii Barat Kabupaten Konawe Kepulauan Tahun 2016. J Ilm Mhs Kesehat Masy Unsyiah [Internet], 1(3):183311. Available from: http://ojs.uho.ac.id/index.php/JIMKESMAS/articl e/view/1087

17. Rusdin, M., Razak, A., Darmawansyah. (2015). Pemanfaatan Pelayanan Kesehatan Masyarakat Pesisir Di Wilayah Kerja Puskesmas Bowong Cindea. 2015; Available from: http://digilib.unhas.ac.id/uploaded_files/temporary /DigitalCollection/MjliYjc4OWNiNTE5ZGMwM GE4NzAzY2UyMWFjMTVINWM2N2QxZWFk $\mathrm{YQ}==$.pdf

18. Irawan, B., Ainy, A. (2018). Analisis FaktorFaktor Yang Berhubungan Dengan Pemanfaatan Pelayanan Kesehatan Pada Peserta Jaminan
Kesehatan Nasional Di Wilayah Kerja Puskesmas Payakabung, Kabupaten Ogan Ilir. J Ilmu Kesehat Masy [Internet], 9(3); 189-97. Available from: https://ejournal.fkm.unsri.ac.id/index.php/jikm/arti cle/view/311

19. Republik Indonesia. (2014). Undang-Undang RI Nomor 36 Tahun 2014 Tentang Tenaga Kesehatan [Internet]. Indonesia; 2014. Available from: https://ktki.kemkes.go.id/info/sites/default/files/U U Nomor 36 Tahun 2014 tentang Tenaga Kesehatan.pdf

20. Maelissa, S.R., Lilipory, M. (2020). Persepsi keluarga dalam memanfaatkan fasilitas pelayanan kesehatan. J Keperawatan [Internet]; 12(4); $807-$ 14. Available from: https://journal.stikeskendal.ac.id/index.php/Kepera watan/article/download/994/595/

21. Darmawan, A.A.K.N. (2016). Faktor-Faktor Yang Mempengaruhi Perilaku Kunjungan Masyarakat Terhadap Pemanfaatan Pelayanan Posyandu Di Desa Pemecutan Kelod Kecamatan Denpasar Barat. J Dunia Kesehat [Internet], 5. Available from:

https://media.neliti.com/media/publications/76442 -ID-faktor-faktor-yang-mempengaruhiperilaku.pdf

Cite This Article: Widya Y. Nurdin et al (2022). Factors Relating to the Utilization of Health Services at the Naioni Community Health Center (Puskesmas) in Alak Subdistrict, Kupang City in 2021. East African Scholars J Med Sci, 5(1), 1420. 